\title{
Student-Student and Student-Teacher Interactions through the Jigsaw II Method in the Teaching of the Economics Subject in Secondary Education
} Mercedes MORERA-FERNANDEZ ${ }^{1}$, Aram MORERA-MESA², Miguel Angel MORERA-FUMERO, Javier HERNANDEZ-PEREZ ${ }^{4}$, Armando Luis MORERA-FUMERO ${ }^{5}$

\section{ARTICLE INFO}

\section{Article History:}

Received 06.06.2019

Received in revised form

22.01.2020

Accepted

Available online 01.03.2020

\begin{abstract}
Peer interactions and teacher student interactions are essential components of learning upon which cooperative learning (CL) is rooted. Empirical data about this type of interactions are scanty. The aim of this research is to compare students' opinions about the student-student and student-teacher interactions in a CL method (Jigsaw II/puzzle) and the conventional teacher learning method after learning an economics teaching unit in a secondary education school. The study was carried out in a secondary education level institute in the island of Tenerife, Canary Islands (Spain) during the 20172018 academic year. Twenty-eight students took part in the study. Students were taught a unit through the conventional teacher exposition method and later through a CL technique (Jigsaw II/puzzle). Peer interactions and teacher-student interaction were evaluated through a 5-point Likertscale. Students were evaluated twice, during the conventional instruction and approximately two weeks later after receiving the CL instruction. The total score of interactions among peers was significantly higher with the CL method than the conventional method (conventional method: 19.92 \pm 2.26 vs CL method: $21.54 \pm 2.75, \mathrm{p}<0.009$ ). There were no significant differences between the methods of learning in the total score of the interaction with the teacher (conventional method: $17.17 \pm 1.61$ vs CL method: $16.37 \pm 2.78, \mathrm{p}<0.098$ ), but in item 9 (interchange of information with the teacher) the score in conventional method was significantly higher than in the CL technique $(4.50 \pm$ 0.59 vs $4.21 \pm 0.72, p<0.016)$. In conclusion, the secondary education students consider that puzzle/jigsaw II CL technique promotes relationships among peers more than conventional learning while there is no difference between the puzzle/jigsaw II CL technique and the conventional learning in the teacher-student relationships.
\end{abstract}

(C) IJERE. All rights reserved

Keywords: ${ }^{1}$

Conventional learning, cooperative learning, jigsaw ii, puzzle technique, secondary education, economics.

\section{INTRODUCTION}

Cooperative learning (CL) can be defined as a teaching technique that involves a small group of learners working together as a team to solve a problem, complete a task, or accomplish a common goal. The members of the group must acknowledge that they are part of a team and that the success or failure of the group will be shared by all members of the group (Artzt \& Newman, 1990). Working in small groups of learners provides a forum in which students ask questions, learn to listen to others' ideas, offer constructive criticism, discuss ideas, make mistakes, and summarize their discoveries in writing (National Council of Teachers of Mathematics (NCTM), 1989). The term CL includes several teaching/learning techniques that have been developed over the years and put into practise in the classroom. Some of the most extensively researched are the Learning Together (Johnson \& Johnson, 1987), Group Investigation (Sharan \& Sharan, 1992), Jigsaw (Aronson, Stephan, Sikes, Blaney, \& Snapp, 1978), Jigsaw II and the Cooperative Integrated Reading and Composition (CIRC) ( Slavin, 1990).

Research on the effects of CL has found that these techniques improve human relationships in heterogeneous groups due to ethnic differences (Slavin \& Cooper, 1999) and differences in mental or physical aptitudes (Madden \& Slavin, 1983). They have also found that they promote cognitive achievement and academic performance, at least when compared to the conventional one. CL offer students "greater opportunity to discuss, to learn from each other and to encourage excellence among themselves" (Slavin \& Cooper, 1999). Likewise, although not so consistently, studies have found that CL methods improve the social status and behaviour of disadvantaged students, although they do not always promote friendship ties (Madden \& Slavin, 1983); prevent problems such as negative reactions to integration and diversity, selfcenteredness or lack of prosocial behaviours; and promote the locus of internal control, altruism and the

1Master in Education. Degree in Business Administration and Management University of La Laguna. Corresponding e-mail: mercedes.morera.2018@gmail.com; orcid.org/0000-0002-7671-294X 2Computer Science Teacher. Ark All Saints Academy. Corresponding e-mail: aram_mm@yahoo.es; orcid.org/0000-0002-6597-6587

3Degree in Physics. IES Las Galletas. Corresponding e-mail: miguelmoreraf@gmail.com; orcid.org/0000-0001-9424-6674

4Degree in Physics. IES Las Galletas. Corresponding e-mail: miguelmoreraf@gmail.com; orcid.org/0000-0001-9424-6674

5Lecturer in psychiatry. School of Medicine. University of La Laguna. Corresponding e-mail: amorera@ull.edu.es; orcid.org/0000-0002-7663-1154 
skills necessary to be a good citizen (Cohen, 1994; Slavin, 1990). CL makes the most of the powerful influence of peer relationships. Students want their peers to do well because an individual's success depends on the success of the group. Furthermore, CL learning supplies intrinsic motivation for learning (Furrer, Skinner, \& Pitzer, 2014). Peer-interactions and teacher-student interactions are basic ingredients which support the learning process. (Serrano \& Pons, 2014). Empirical research in some educational topics and educational levels is scanty. The introduction of the economics subject in secondary education is relatively recent compared to more traditional subjects such as literature (Göer, 2010), science (Topping et al., 2011) or mathematics (Pons, Prieto, Lomeli, Bermejo, \& Bulut, 2014). In a recent systematic review about the economics subject in secondary education it was found scanty empirical research about the implementation of the Jigsaw II CL technique in secondary education (Morera-Fernandez, Morera-Mesa, \& Morera-Fumero, 2020). Furthermore, the existing investigation elicited controversial results, having found that the Jigsaw II CL technique was effective in increasing the outcome in one group of students and neutral in another group of students (Rokhmah \& Subroto, 2019). Because of the scarce empirical research on the topic of economy in secondary education, we have planned this research with the aim of comparing students' opinions about the student-student and student-teacher interactions in a CL method (Jigsaw II/puzzle) and the conventional teaching method after receiving a topic of economy in a secondary education school.

\section{METHOD}

\section{Participants}

The students' sample was comprised by two classes that studied economics in their academic course. The study was carried out in a secondary education level school (Instituto de Educación Secundaria Benito Pérez Armas) in the island of Tenerife, Canary Islands (Spain) during the 2017-2018 academic year. Class 1 was comprised by 13 students ( 9 females and 4 male) and class 2 was comprised by 15 students ( 9 females and 6 male). The age of the participant ranged from a minimum of 16 to a maximum of 19 and all of them were Caucasians.

\section{Instruments and procedure}

To carry out this research, we use the cooperative learning procedure known as the Jigsaw II or also known as Expert Puzzle (R. Slavin, 1990). We selected the Jigsaw/Puzzle cooperative technique (JPCT) because in the JPCT the students are evaluated according to its result, with the same reward for all members of the group.

Briefly, the JPCT consists in organizing the classroom activity in order to make the students dependent on each other to succeed. It breaks classes into small groups (4-5 members) and breaks assignments into pieces (triangle, square, circle, rhombus), according to the number of subjects, that the group assembles to complete the jigsaw/puzzle. So, each subject of each group receives a piece of the in-class assignment, this is called the home-group. Then, working individually, each student learns about his/her piece in the home-group. In the next step, students gather into groups divided by pieces of assignments and each member presents again to the piece-assignment group, this is called the expert-group. Within the same expert-groups, students confront, discuss, reconcile points of view and synthesize the information with the aim of creating a final report. Finally, the original groups or home-groups reconvene and listen to the presentations from each member. The final presentations provide all group members with an understanding of their own material, as well as the findings that have emerged from expert-group discussion.

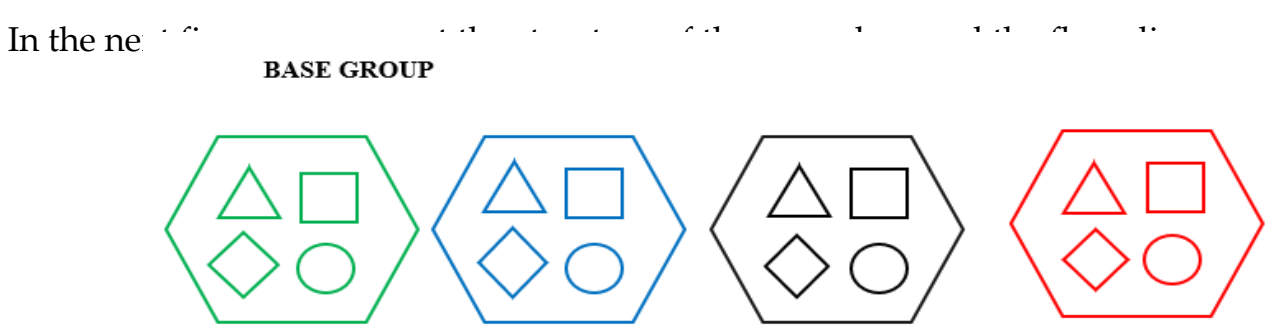

EXPERT GROUP

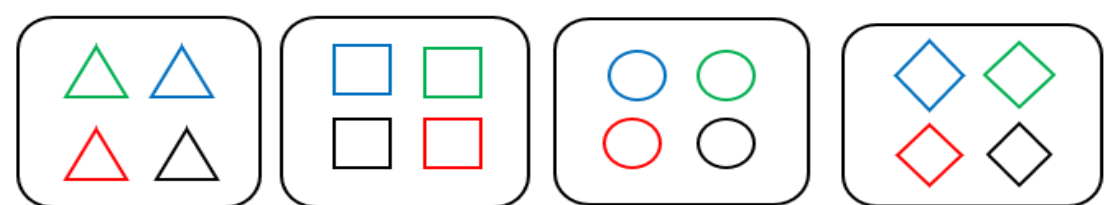




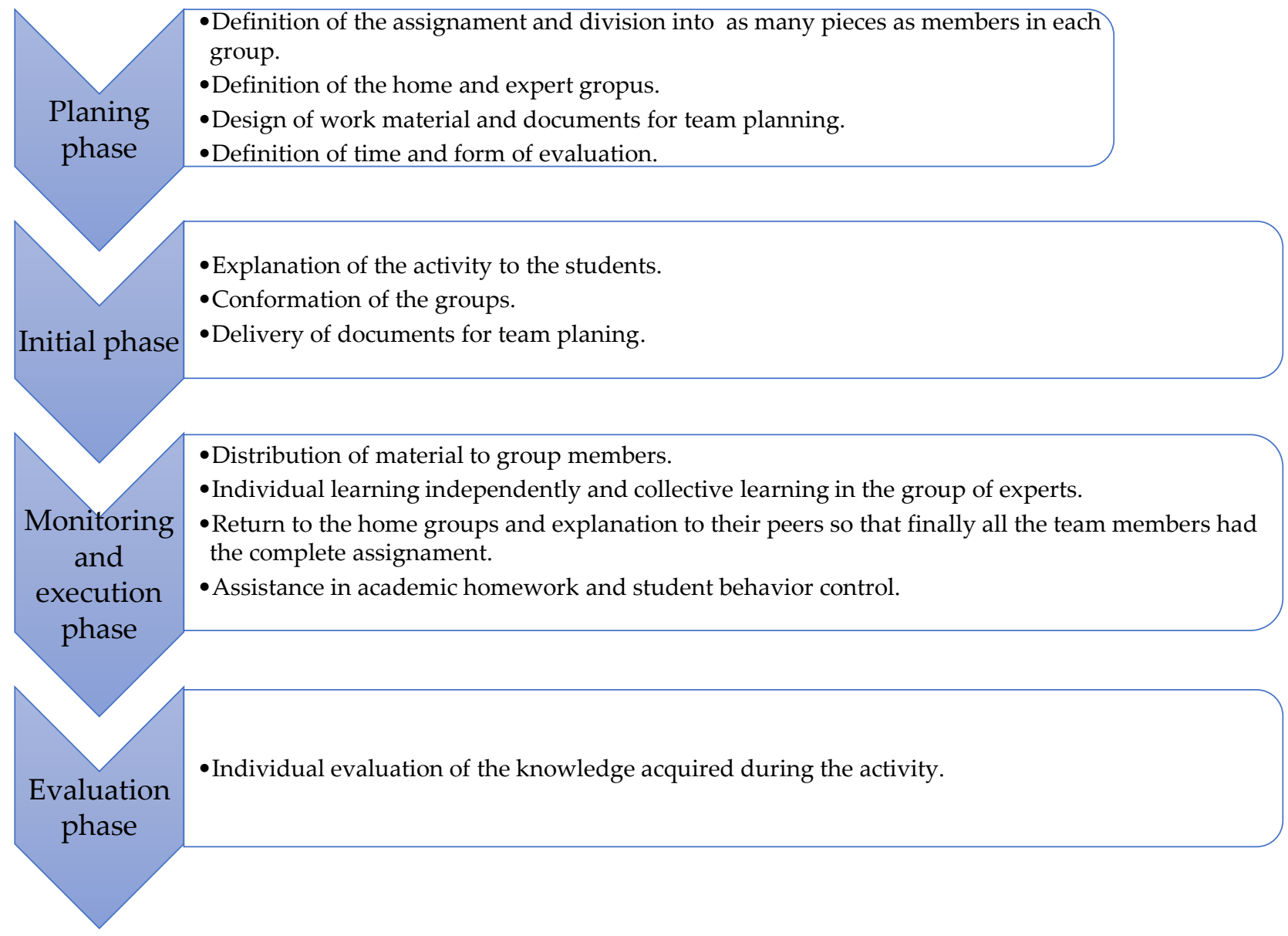

Figure 1: Structure of the procedure and flow diagram.

The working topic for our lessons was selected from the material of the subject, this is, "Money and Monetary Policy and International trade and the globalization of the Economy". With conventional methodology of learning four hours are typically assigned to develop this topic while with the JPCT we assigned six hours. Because our sample was comprised by 28 students, the whole sample was divided in seven groups of four students.

Students were evaluated twice, within the conventional instruction and approximately two weeks later after receiving the cooperative learning instruction.

\section{Measurement}

In order to have a measure of the two types of learning (conventional and cooperative), a questionnaire based on previous studies (Liu, 2003; McMillan \& Hwang, 2002; Vallet-Bellmunt, RiveraTorres, Vallet-Bellmunt, \& Vallet-Bellmunt, 2016) was presented to the students. The questionnaire contains nine items, items 1 to 5 questions about the relationship among students and items 6 to 9 refers to the relation with the teacher. Each item is evaluated in a five points Likert scale. So, the range score of the interactions among peer's scale is 5 points as the minimum and 30 points as the maximum. With respect to the interactions with the teacher (four items), the minimum score is 4 point and the maximum 20 points. Appendix 1 has a sample of the CL methodology questionnaire while appendix 2 includes a sample of the conventional questionnaire.

\section{Statistical analysis}


The statistical analysis was carried out by using the SPSS 25 program (Social Package for the Social Sciences, version 25). Comparisons between conventional and CL methods was carried out by using the statistic $t$-test for paired data (the same subjects received conventional and cooperative learning). The level of significance was set at 0.05 , while the statistical tests were two-tailed. Data are presented by their mean \pm standard deviation (SD). The comparison of the indicators of both methodologies are presented by the value of the $t$ statistic value $(t)$, the degrees of freedom $(\mathrm{df})$ and the $p$-value $(p)$.

\section{RESULTS}

The study sample was comprised by 28 students, being more female than male (64\% vs 36\%) with an age ranging from 16 to 19 years for the whole sample.

In table 1 we present the results of the item by item and total scale comparisons in the interactions among peers.

\begin{tabular}{|c|c|c|c|c|c|c|}
\hline Items & The activity carried out ... & $\begin{array}{l}\text { Type of } \\
\text { Learning }\end{array}$ & Mean \pm SD & $\mathrm{t}$ & $\mathrm{f}$ & $\mathrm{P}$ \\
\hline \multirow{2}{*}{ Item 1} & \multirow{2}{*}{ Improves the interactions among peers } & Conventional & $3.87 \pm 0.68$ & \multirow{2}{*}{3.11} & \multirow[b]{2}{*}{3} & \multirow{2}{*}{0.005} \\
\hline & & Cooperative & $4.33 \pm 0.56$ & & & \\
\hline \multirow{2}{*}{ Item 2} & \multirow{2}{*}{$\begin{array}{l}\text { Gives me the opportunity to } \\
\text { interchange opinions with my peers }\end{array}$} & Conventional & $4.29 \pm 0.62$ & \multirow{2}{*}{-1.16} & \multirow[b]{2}{*}{3} & \multirow{2}{*}{0.257} \\
\hline & & Cooperative & $4.46 \pm 0.59$ & & & \\
\hline \multirow{2}{*}{ Item 3} & \multirow{2}{*}{ Improves the dialog among peers } & Conventional & $4.21 \pm 0.51$ & \multirow{2}{*}{-2.29} & \multirow[b]{2}{*}{3} & \multirow{2}{*}{0.032} \\
\hline & & Cooperative & $4.50 \pm 0.59$ & & & \\
\hline \multirow{2}{*}{ Item 4} & \multirow{2}{*}{$\begin{array}{l}\text { Allows the interchange of information } \\
\text { among peers }\end{array}$} & Conventional & $3.87 \pm 0.90$ & \multirow{2}{*}{-1.00} & \multirow[b]{2}{*}{3} & \multirow{2}{*}{0.338} \\
\hline & & Cooperative & $4.08 \pm 0.93$ & & & \\
\hline \multirow{2}{*}{ Item 5} & \multirow{2}{*}{ Foster new ways of relations } & Conventional & $3.67 \pm 0.82$ & \multirow{2}{*}{-2.51} & \multirow[b]{2}{*}{3} & \multirow{2}{*}{0.020} \\
\hline & & Cooperative & $4.17 \pm 0.76$ & & & \\
\hline \multirow{2}{*}{$\begin{array}{l}\text { Total } \\
\text { score }\end{array}$} & & Conventional & $19.92 \pm 2.26$ & \multirow{2}{*}{-2.83} & \multirow[b]{2}{*}{3} & \multirow{2}{*}{0.009} \\
\hline & & Cooperative & $21.54 \pm 2.75$ & & & \\
\hline
\end{tabular}

Table 1: Item by item and total scale score comparisons in the interactions among peers by method of learning.

As it can be seen from table 1 the total score of interactions among peers was significantly higher with the CL method compared to the conventional method. Three items of the scale contribute significantly to this difference, item 1, item 3 and item 5 scored significantly higher in the cooperative methodology than in the conventional methodology. Items 2 and 4 scored higher in the cooperative compared to the conventional method, but the comparison did not reach statistical significance.

Table 2 presents the results of the item by item and total scale score comparisons in the interactions with the teacher.

\begin{tabular}{|c|c|c|c|c|c|c|}
\hline Items & The activity carried out ... & $\begin{array}{c}\text { Type of } \\
\text { Learning }\end{array}$ & Mean \pm SD & $\mathrm{t}$ & $\mathrm{df}$ & $\mathrm{P}$ \\
\hline \multirow{2}{*}{ Item 6} & \multirow{2}{*}{$\begin{array}{l}\text { Facilitates the interaction with the } \\
\text { teacher }\end{array}$} & Conventional & $4.12 \pm 0.45$ & \multirow{2}{*}{0.77} & \multirow{2}{*}{23} & \multirow{2}{*}{0.450} \\
\hline & & Cooperative & $4.00 \pm 0.83$ & & & \\
\hline \multirow{2}{*}{ Item 7} & \multirow{2}{*}{$\begin{array}{l}\text { Gives me the opportunity to } \\
\text { interchange opinions with the }\end{array}$} & Conventional & $4.33 \pm 0.56$ & \multirow{2}{*}{1.24} & \multirow{2}{*}{23} & \multirow{2}{*}{0.228} \\
\hline & & Cooperative & $4.08 \pm 0.83$ & & & \\
\hline
\end{tabular}




\begin{tabular}{|c|c|c|c|c|c|c|}
\hline & teacher & & & & & \\
\hline \multirow{2}{*}{ Item 8} & \multirow{2}{*}{$\begin{array}{l}\text { Facilitates the dialogue with the } \\
\text { teacher }\end{array}$} & Conventional & $4.21 \pm 0.72$ & \multirow{2}{*}{0.90} & \multirow{2}{*}{23} & \multirow{2}{*}{0.377} \\
\hline & & Cooperative & $4.10 \pm 0.72$ & & & \\
\hline \multirow{2}{*}{ Item 9} & \multirow{2}{*}{$\begin{array}{l}\text { Allows the interchange of } \\
\text { information with the teacher }\end{array}$} & Conventional & $4.50 \pm 0.59$ & \multirow{2}{*}{2.60} & \multirow{2}{*}{23} & \multirow{2}{*}{0.016} \\
\hline & & Cooperative & $4.21 \pm 0.72$ & & & \\
\hline \multirow{2}{*}{$\begin{array}{l}\text { Total } \\
\text { score }\end{array}$} & & Conventional & $17.17 \pm 1.61$ & \multirow{2}{*}{1.73} & \multirow{2}{*}{23} & \multirow{2}{*}{0.098} \\
\hline & & Cooperative & $16.37 \pm 2.78$ & & & \\
\hline
\end{tabular}

Table 2: Item by item and total scale score comparisons in the interactions with the teacher by method of learning.

There were no significant differences between the two methods of learning in the total score of the interaction with the teacher. In general, the students scored higher the conventional method than the cooperative method, except item 9 where the comparison of both methods of learning elicited significantly higher scores with the conventional than the cooperative methodology.

\section{DISCUSSION AND CONCLUSIONS}

The purpose of this study was to compare the student-student and student-teacher interaction in two different learning techniques, the jigsaw II or puzzle technique of $\mathrm{CL}$ and the conventional technique.

As far as we know this is the first study on the topic of economy in secondary education where two essential components in which the CL techniques are rooted, peer and teacher-student interactions, are studied at the same time in the same sample. Our research found that students considered that the jigsaw II o puzzle CL technique provided them with more opportunities to interact with their peers than the conventional learning.

Regarding student-teacher interactions, the students reported that the conventional learning technique allowed them to have more interactions with the teacher than the CL technique, though this difference did not reach statistical significance. However, the item of "interchange of information with the teacher" scored significantly higher in the conventional method than in the CL method. This result is expected because in the conventional learning most of the interactions are produced in a bidirectional way student-teacher-student and the interactions student-student are not the norm.

Previous researches with CL techniques have focused in the student outcome, having found that CL improved the outcome in some students but does not affect the outcome in other students (Rokhmah \& Subroto, 2019). We did not implement any measure of students' outcome because the duration of the research was too short and limited only to one unit within the subject.

The main limitation of our study is the small number of subjects that form the sample of students, so our conclusions should be considered with caution. The second limitation of our study was that we did not measure the outcome of the learning technique. In our opinion the outcomes of both learning techniques would be better studied trough a longer period where the students receive both learning techniques. Our research has also a strength, the paired design, the same subjects received both experimental conditions, in our opinion this type design gives consistency to our results.

In conclusion, the secondary education students consider that puzzle/jigsaw CL technique promotes more than the conventional learning the relationships among peers while there is no difference between the puzzle/jigsaw CL technique and the conventional learning in the teacher-student relationships.

\section{REFERENCES}

Aronson, E., Stephan, C., Sikes, J., Blaney, N., \& Snapp, M. (1978). The Jigsaw Classroom. Beverly Hills, CA: Sage Publication. 
Artzt, A. F., \& Newman, C. M. (1990). Cooperative learning. Mathematics Teacher, 83(September), $448-452$.

Cohen, E. G. (1994). Restructuring the Classroom: Conditions for Productive Small Groups. Review of Educational Research, 64(1), 1-35.

Furrer, C. J., Skinner, E. A., \& Pitzer, J. R. (2014). The influence of teacher and peer relationships on students' classroom engagement and everyday motivational resilience. Teachers College Record, 116(13), 101-123.

Göer, A. (2010). A comparative research on the effectivity of cooperative learning method and jigsaw technique on teaching literary genres. Educational Research and Reviews, 5(8), 439-445.

Johnson, D. W., \& Johnson, R. P. (1998). Learning Together and Alone: Co-Operative, Competitive and Individualistic Learning (3rd ed.). Allyn \& Bacon.

Liu, Y. (2003). Developing a scale to measure the interactivity of websites. Journal of Advertising Research, 43(2), 207-216.

Madden, N. A., \& Slavin, R. E. (1983). Mainstreaming Students with Mild Handicaps: Academic and Social Outcomes. Review of Educational Research, 53(4), 519-569.

McMillan, S. J., \& Hwang, J. S. (2002). Measures of perceived interactivity: An exploration of the role of direction of communication, user control, and time in shaping perceptions of interactivity. Journal of Advertising, 31(3), 28-42.

Morera-Fernandez, M., Morera-Mesa, A., \& Morera-Fumero, A. L. (2020). Cooperative learning: A systematic review of the economy subject in the curriculum of secondary education. International Journal of Educational Research Review, 5(1), 83-86.

National Council of Teachers of Mathematics (NCTM). (1989). Curriculum and Evaluation Standards for School Mathematics. Reston, Virginia: National Council of Teachers of Mathematics.

Pons, R. M., Prieto, M. D., Lomeli, C., Bermejo, M. R., \& Bulut, S. (2014). Cooperative learning in mathematics: A study on the effects of the parameter of equality on academic performance. Anales de Psicologia, 30(3), 832-840.

Rokhmah, N. F., \& Subroto, W. T. (2019). Application of cooperative learning jigsaw type to improve learning outcomes of economic introduction and business. International Journal of Educational Research Review, 4(2), 238-244.

Serrano, J. M., \& Pons, R. M. (2014). Introduction: Cooperative learning. Anales de Psicologia, 30(3), 781-784.

Sharan, S., \& Sharan, Y. (1992). Expanding cooperative learning through group investigation. New York: Teacher's College Press.

Slavin, R. (1990). Cooperative learning: Theory, research, and practice. Englewood Cliffs, N.J.: Prentice Hall.

Slavin, R. E., \& Cooper, R. (1999). Improving intergroup relations: Lessons learned from cooperative learning programs. Journal of Social Issues, 55(4), 647-663.

Topping, K. J., Thurston, A., Tolmie, A., Christie, D., Murray, P., \& Karagiannidoud, E. (2011). Cooperative learning in science: Intervention in the secondary school. Research in Science and Technological Education, 29(1), 91-106.

Vallet-Bellmunt, T., Rivera-Torres, P., Vallet-Bellmunt, I., \& Vallet-Bellmunt, A. (2016). Eficiencia del plan de marketing como técnica de aprendizaje cooperativo. European Research on Management and Business Economics, 22(1), 17-24.

\section{APPENDIX 1. COOPERATIVE LEARNING SURVEY}

Through this survey describe what the group activity has given you

Strongly
disagree

Disagree \begin{tabular}{l|l} 
Neither & \\
Agree Nor & Agree
\end{tabular} Disagree
Strongly

agree 


\begin{tabular}{|c|c|c|c|c|c|c|}
\hline \multirow{5}{*}{$\begin{array}{l}\text { Peer } \\
\text { interaction } \\
\text { / Personal } \\
\text { relations } \\
\text { The group } \\
\text { activity } \\
\text { carried out } \\
\text {... }\end{array}$} & $\begin{array}{l}\text { It facilitates } \\
\text { communication/dialogue with } \\
\text { colleagues }\end{array}$ & & & & & \\
\hline & $\begin{array}{l}\text { It gives me the opportunity to } \\
\text { exchange opinions, information } \\
\text { with my colleagues }\end{array}$ & & & & & \\
\hline & $\begin{array}{l}\text { It drives me to listen to my } \\
\text { classmates' explanations }\end{array}$ & & & & & \\
\hline & $\begin{array}{l}\text { Promote personal relationships } \\
\text { with my classmates }\end{array}$ & & & & & \\
\hline & Promote new forms of relationship & & & & & \\
\hline & & $\begin{array}{l}\text { Strongly } \\
\text { disagree }\end{array}$ & Disagree & $\begin{array}{l}\text { Neither } \\
\text { Agree Nor } \\
\text { Disagree } \\
\end{array}$ & Agree & $\begin{array}{c}\text { Strongly } \\
\text { agree }\end{array}$ \\
\hline $\begin{array}{l}\text { Interaction } \\
\text { with the }\end{array}$ & $\begin{array}{l}\text { Facilitates interaction with the } \\
\text { teacher }\end{array}$ & & & & & \\
\hline $\begin{array}{l}\text { teacher / } \\
\text { Personal } \\
\text { relations }\end{array}$ & $\begin{array}{l}\text { It gives me the opportunity to } \\
\text { exchange opinions / information } \\
\text { with the teacher }\end{array}$ & & & & & \\
\hline The group & Facilitate dialogue with the teacher & & & & & \\
\hline $\begin{array}{c}\text { activity } \\
\text { carried out } \\
\ldots\end{array}$ & $\begin{array}{l}\text { Allows the exchange of } \\
\text { information with the teacher }\end{array}$ & & & & & \\
\hline
\end{tabular}




\section{APPENDIX 2. CONVENTIONAL LEARNING SURVEY}

Through this survey describe what the theoretical / practical classes usually give you

\begin{tabular}{|c|c|c|c|c|c|c|}
\hline \multirow{2}{*}{$\begin{array}{c}\text { Interaction } \\
\text { with classmates } \\
\text { / Personal } \\
\text { relationships }\end{array}$} & $\begin{array}{l}\text { It facilitates } \\
\text { communication / dialogue } \\
\text { with colleagues }\end{array}$ & & & & & \\
\hline & $\begin{array}{l}\text { It gives me the } \\
\text { opportunity to exchange } \\
\text { opinions / information } \\
\text { with my colleagues }\end{array}$ & & & & & \\
\hline \multirow{3}{*}{$\begin{array}{c}\text { Classes normally } \\
\ldots\end{array}$} & $\begin{array}{l}\text { It drives me to listen to my } \\
\text { classmates' explanations }\end{array}$ & & & & & \\
\hline & $\begin{array}{l}\text { Promote personal } \\
\text { relationships with my } \\
\text { classmates }\end{array}$ & & & & & \\
\hline & $\begin{array}{l}\text { Promote new forms of } \\
\text { relationship }\end{array}$ & & & & & \\
\hline & & $\begin{array}{l}\text { Strongly } \\
\text { disagree }\end{array}$ & Disagree & $\begin{array}{l}\text { Neither } \\
\text { Agree Nor } \\
\text { Disagree }\end{array}$ & Agree & $\begin{array}{c}\text { Strongly } \\
\text { agree }\end{array}$ \\
\hline \multirow{3}{*}{$\begin{array}{l}\text { Interaction } \\
\text { with the } \\
\text { teacher / } \\
\text { Personal } \\
\text { relations }\end{array}$} & $\begin{array}{l}\text { Facilitates interaction with } \\
\text { the teacher }\end{array}$ & & & & & \\
\hline & $\begin{array}{l}\text { It gives me the } \\
\text { opportunity to exchange } \\
\text { opinions / information } \\
\text { with the teacher }\end{array}$ & & & & & \\
\hline & $\begin{array}{l}\text { Facilitate dialogue with } \\
\text { the teacher }\end{array}$ & & & & & \\
\hline $\begin{array}{c}\text { Classes normally } \\
\ldots\end{array}$ & $\begin{array}{l}\text { Allows the exchange of } \\
\text { information with the } \\
\text { teacher }\end{array}$ & & & & & \\
\hline
\end{tabular}

